\title{
STUDY OF THE DIETARY MINERALS INTAKE OF CHILDREN WITH EARLY CHILDHOOD CARIES
}

\author{
Mariana I. DIMOVA-GABROVSKA ${ }^{1}$, Desislava G. DIMITROVA ${ }^{2}$ \\ ${ }^{1}$ Department of Prosthetic Dentistry, Faculty of Dental Medicine, Sofia, Bulgaria \\ 2 Dental Clinic „Edinstvo“, Sofia, Bulgaria
}

\author{
Received 10 July 2019, Accepted 18 August 2019 \\ https://doi.org/10.31688/ABMU.2019.54.3.21
}

\begin{abstract}
Introduction. Early childhood diet is of critical importance for the processes of tooth dentition, formation of organic matrix, mineralization and maturation of dental structures. The involvement of inorganic elements in the building up of bone and teeth tissue in childhood is an essential process, determining the achievement of their peak density. Considering the scientists' interest in oral health, with emphasis on childhood and increasing of caries incidence at this age, it is necessary to investigate deeply the issue at national level as well.
\end{abstract}

The objective of the study was to investigate the dietary intake of inorganic elements - calcium, phosphorus, magnesium, fluorine, sodium, and iron in children with early childhood caries.

Material and methods. The dietary mineral intake of 53 children, aged 3-6 years, diagnosed with early childhood caries, was studied by the 24-hour dietary recall method. The data revealed by parents' responses were processed statistically, compared to the referent values for inorganic elements intake in this age.

Results. The results of investigated group of children revealed an average daily intake of calcium of $473.4 \pm 222.5 \mathrm{mg}$, phosphorus $745 \pm 177 \mathrm{mg}$, fluorine $0.8 \pm 0.37 \mathrm{mg}$, magnesium $139 \pm 43 \mathrm{mg}$, iron $6.7 \pm 4.64$ $\mathrm{mg}$, and of sodium $1159 \pm 529 \mathrm{mg}$.

\section{Résumé}

Étude sur la consommation alimentaire de minéraux chez les enfants atteints de carie dentaire dans la petite enfance

Introduction. L'alimentation pendant la petite enfance est de la plus haute importance pour les processus de germination dentaire, la formation de la matrice organique, la minéralisation et la maturation des structures dentaires. L'implication d'éléments inorganiques dans le développement des os et des tissus dentaires chez l'enfant est un processus essentiel pour la réalisation de leur densité maximale. Étant donné l'intérêt scientifique actuel pour la santé bucco-dentaire, l'accent étant mis sur l'enfance et l'augmentation de la propagation des cavités à cet âge, une étude plus approfondie du problème est également nécessaire au niveau national.

L'objectif de l'étude est d'étudier l'apport alimentaire en éléments inorganiques - calcium, phosphore, magnésium, fluorure, sodium et fer chez les enfants atteints de carie dentaire dans la petite enfance.

Matériel et méthodes. L'ingestion de minéraux dans l'alimentation de 53 enfants âgés de 3 à 6 ans chez lesquels un diagnostic de carie de la petite enfance a été diagnostiqué a été examinée à l'aide de la méthode de réponse de 24 heures. Les données reçues des parents 
Conclusions. The detected lower intake of calcium, magnesium, fluorine could be considered as risk factor for caries development and the other elements are associated with children's general health status. The specificity of the needs and health status requires complex caries treatment starting in early childhood together with adequate diet.

Keywords: nutrition, inorganic substances, early childhood, caries. des enfants sont traitées statistiquement par rapport aux valeurs de référence pertinentes pour l'ingestion d'éléments inorganiques à cet âge.

Résultats: Les résultats pour le groupe d'étude a montré une ration quotidienne moyen en calcium de $473,4 \pm 222,5 \mathrm{mg}$, en phosphore de $745 \pm 177 \mathrm{mg}$, en fluor de 0,8 $\pm 0,37 \mathrm{mg}$, en magnésium de $139 \pm 43 \mathrm{mg}$, en fer de 6,7 $\pm 4,64 \mathrm{mg}$ et en sodium de $1159 \pm 529 \mathrm{mg}$

Conclusions. La consommation réduite de calcium, de magnésium et de fluor peut être considérée comme un facteur de risque pour le développement de la carie et les autres éléments sont associés à l'état de santé général des enfants. Les besoins spécifiques et l'état de santé nécessitent un traitement complexe des caries de la petite enfance accompagné d'un régime alimentaire adéquat.

Mots-clés: nutrition, substances inorganiques, carie de la petite enfance.

\section{INTRODUCTION}

According to the World Health Organization (WHO) data, caries is among the most frequently diagnosed diseases, involving $60-90 \%$ of children in pre-school and school age ${ }^{1}$. Carious destruction in child age causes a number of sequels, such as changes in chewing performance, disturbed speech, deteriorated esthetics and development of orthodontic deformations ${ }^{2}$.

The term „early childhood caries“ (ECC) is used to describe a type of caries developing in children aged 1.5 years ${ }^{3}$. The relationship between a rich carbohydrate diet and lower mineral intake, and caries process initiation has been proven ${ }^{4}$.

ECC develops at non-predilection points - vestibular and lingual surfaces of the upper front teeth and progresses passing through several major stages ${ }^{5}$. The disorders in teeth structures, especially in the front sectors, affect the child's general health status, self-confidence and life quality ${ }^{6}$.

The consumed nutrients affect teeth structures by two mechanisms - post-resorptive and pre-resorptive ${ }^{7}$. The resorbed nutrients exert endogenous impact on the teeth before tooth break. This affects tooth dentition, formation of organic matrix and mineralization processes.

According to Psoter $^{8}$, chronic malnutrition in childhood can cause delayed tooth breaking and replacement of milk teeth as well as increased risk for development of caries and occurrence of enamel and dentin hypoplasia. The pre-resorptive effect of food follows tooth break and is associated with the establishment of cariogenic or caries-protective oral environment?

Some researchers ${ }^{9}$ have found that foods and beverages, such as milk and dairy products (white cheese, yellow cheese) and fluorinated mineral water exerted caries-protective effect. Those products increase the amounts of calcium, phosphorus, fluorine and proteins in the plaque, stimulate saliva electric currents through altering the oral $\mathrm{pH}$, mitigate the hazardous carbohydrate effect and ensure the remineralization processes of the attacked dental surfaces.

Bakardziev's data ${ }^{10}$ obtained from a survey of children's dietary habits showed that $16.77 \%$ did not like milk, 27\% did not like white cheese and 25\% did not like yellow cheese. This means that many children do not consume enough minerals for teeth building-up and protection.

It is known that carious injuries affect chewing efficacy that is a prime cause for restriction of some food intake, inadequate primary nutrient processing, initiation of gastrointestinal disorders, etc ${ }^{11}$.

According to Sheiham ${ }^{12}$, untreated carious lesions cause pain and discomfort at eating. Certain deviations occur in the quality and quantity of consumed nutrients - the patients restrain only to several types of consumed foods that usually are insufficient to satisfy the physiological needs of the organism at this age.

Clarke et al proved that all examined children with ECC have malnutrition signs - low weight compared to referent values for the age group ${ }^{13}$. The study performed by Abolfotouh et al supported that finding confirming that young children with low weight had higher rate of caries incidence in a temporary dentition compared to those with normal weight ${ }^{14}$. 
The AIM OF THE STUDY was to investigate the dietary intake of inorganic elements - calcium, phosphorus, magnesium, fluorine, sodium and iron of children with early childhood caries.

\section{Material AND Methods}

The studied group consisted of a total of 53 patients (25 boys, 28 girls), aged 3 - 6 years (mean age $4.08 \pm 0.96$ years). All children, after a total dental examination, were diagnosed with childhood caries.

During the examination the children and their parents described in details the foods and beverages consumed for a 24-hour period. The dietary intake was assessed on the basis of the amount consumed food products referring to their composition data listed in the Bulgarian Tables of Foods Chemical Composition. The data were processed with Alimenta software ${ }^{15}$, calculating the daily intake of calcium (mg), phosphorus (mg), fluorine (mg), magnesium $(\mathrm{mg})$, iron (mg) and sodium (mg).

The results were processed statistically with SPSS v 20.0 software, applying descriptive statistics, $\chi 2$ - criterion, Fisher's exact test, t-test and variation analysis.

The graphic presentation was made using MS Excel 2010.

\section{Results}

\section{Calcium intake}

Almost all examined children (81.1\%) reported calcium intake under the age-related reference values. Only $13.2 \%$ showed calcium intake complying with the referent values and the other $5.6 \%$ consume more than the age needs.

The average daily calcium intake was $473.4 \pm$ $222.5 \mathrm{mg}$, that was with $327 \mathrm{mg}$ less than the amount recommended for this age group $(800 \mathrm{mg})^{16}$. The established difference was statistically significant $(\mathrm{P}=$ 0.000) (Fig. 1).

\section{Phosphorus intake}

The evaluation of the dietary phosphorus intake showed that the greatest percentage rate $(71.7 \%)$ of the children had phosphorus intake exceeding the age-related reference values. Less than $1 / 4$ of the young patients $(22.6 \%)$ reported amount of dietary phosphorus complying with the age-related reference values for adequate intake. The remaining 5.7\% showed low phosphorus intake.

A mean daily intake with standard deviation of $745 \pm 177 \mathrm{mg}$ was established for all investigated children - exceeding by $195 \mathrm{mg}$ the age-related

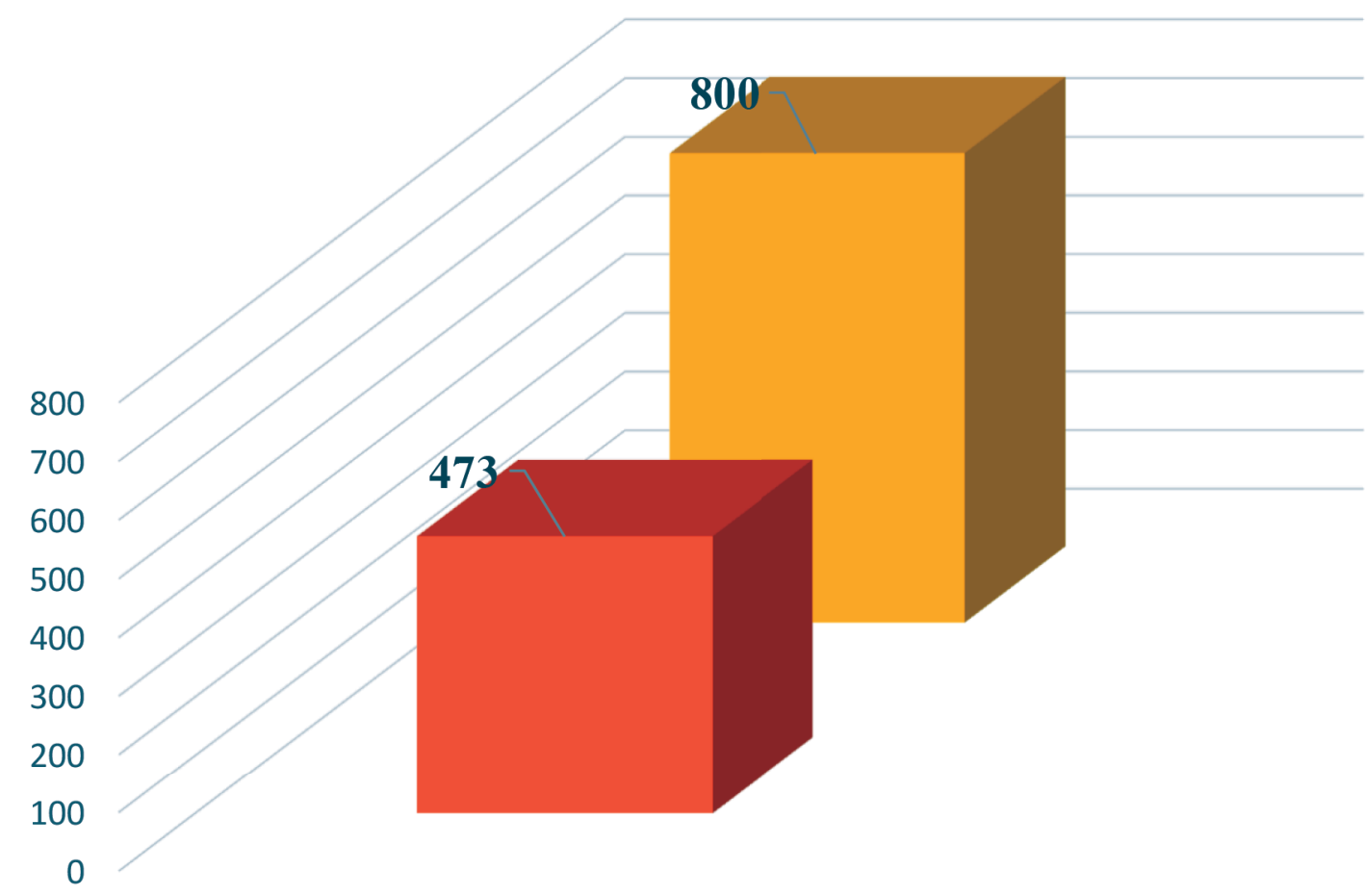

Average daily intake $\quad$ Recommended intake

Fig. 1. Mean daily and recommended calcium intake (mg) 


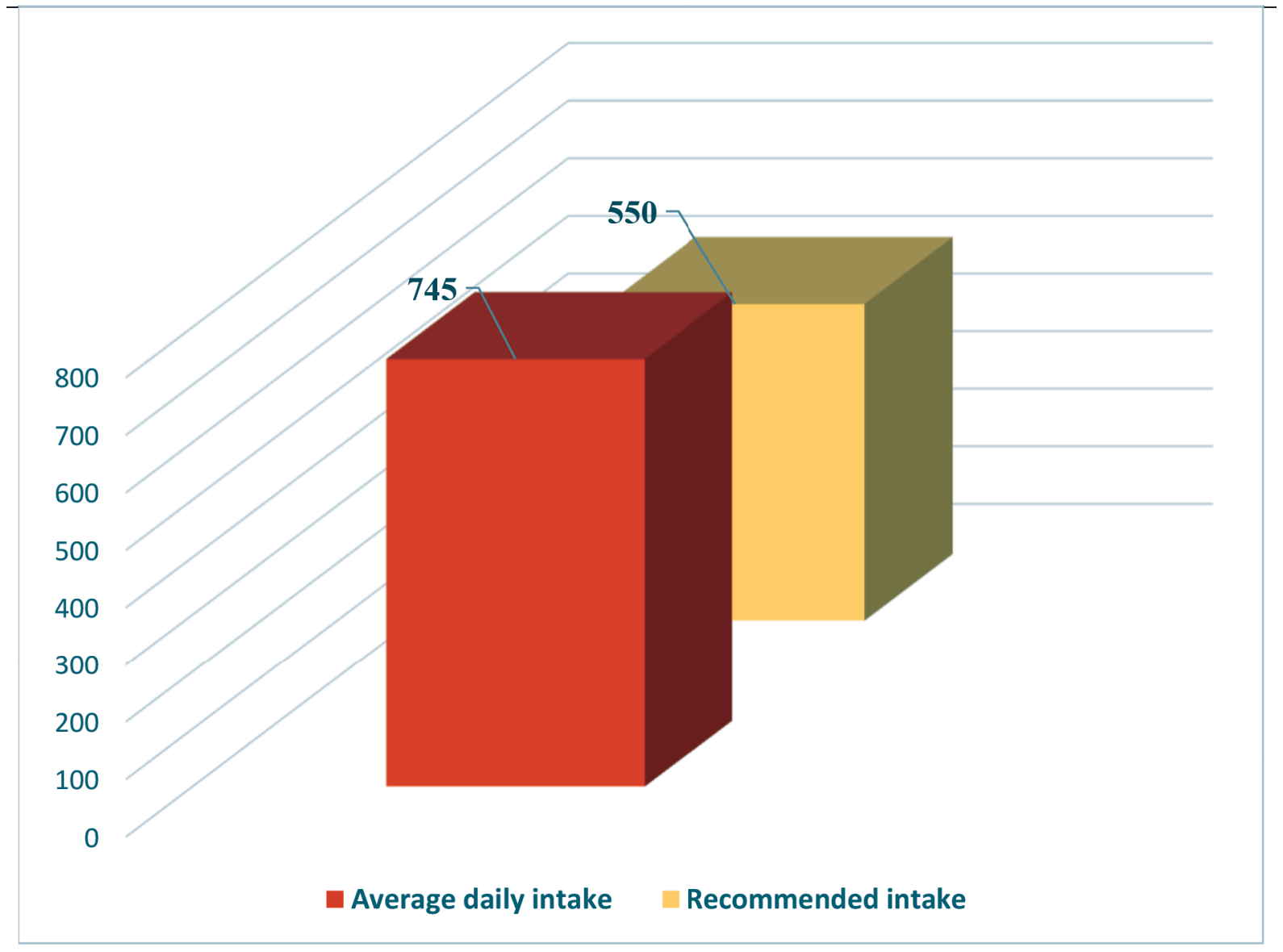

Fig. 2. Mean daily and recommended phosphorus intake (mg)

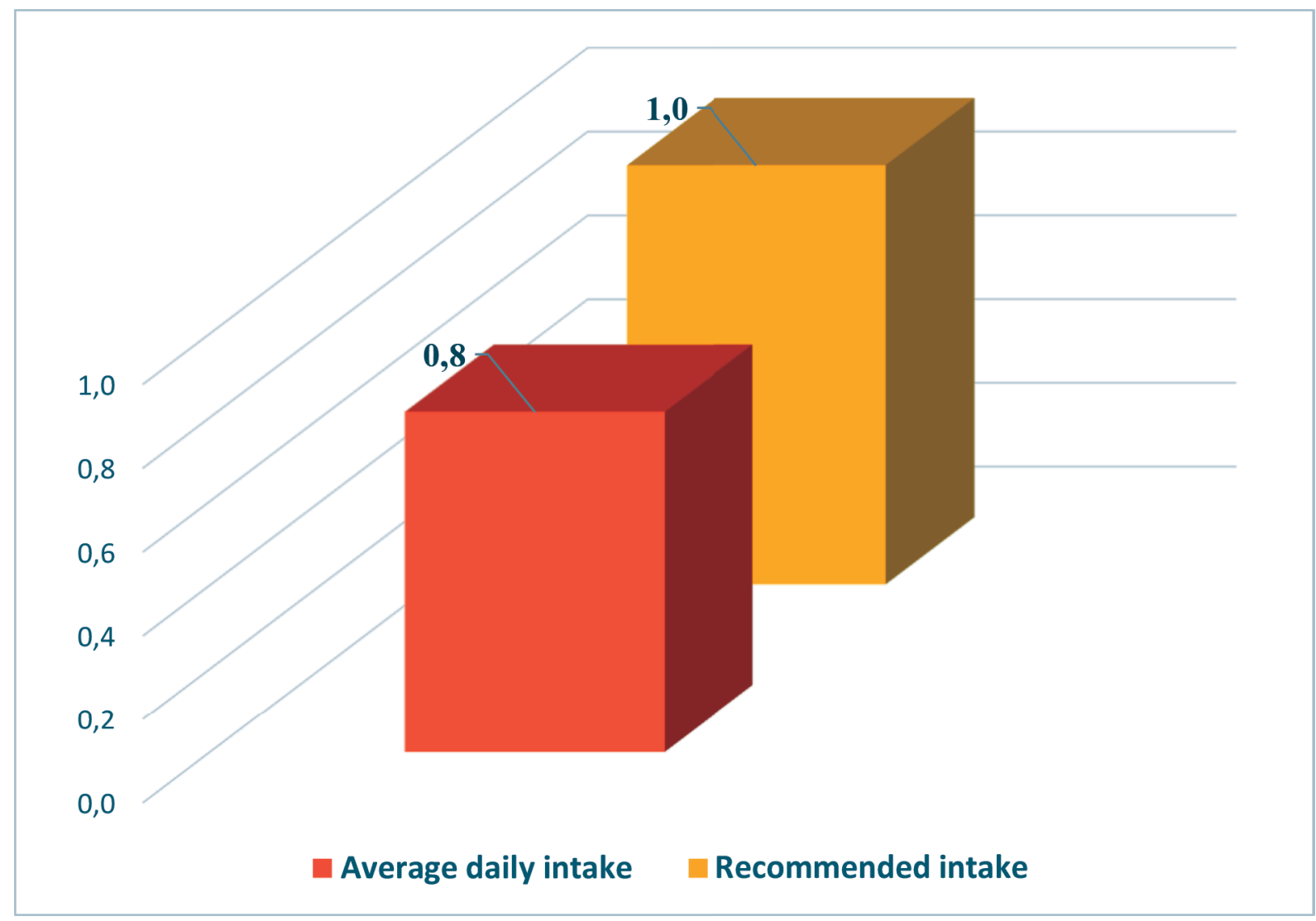

Fig. 3. Mean daily and recommended fluorine intake (mg) 


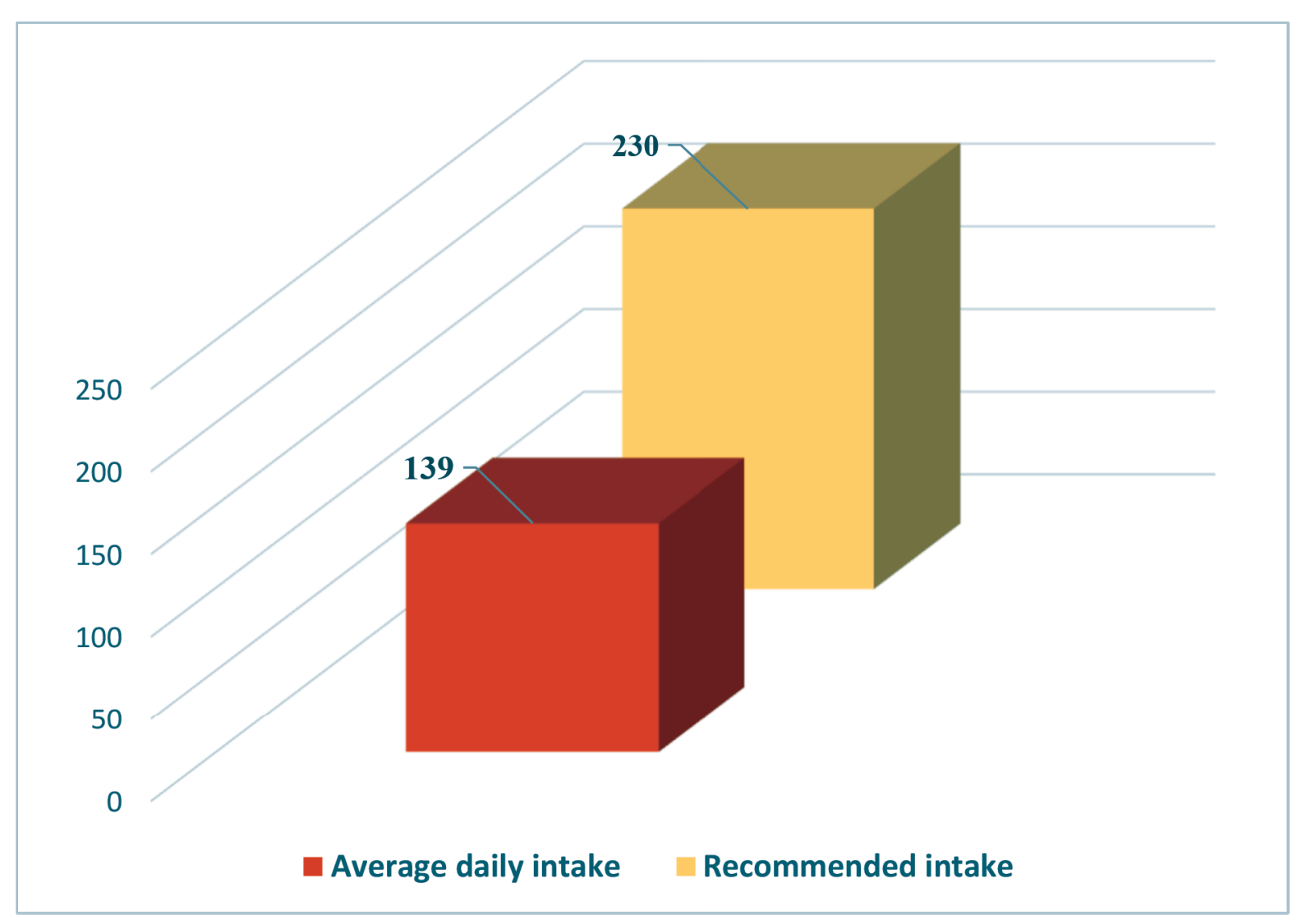

Fig. 4. Mean daily and recommended magnesium intake (mg)

recommended intake values $(550 \mathrm{mg})^{16}$. The determined difference was statistically significant $(\mathrm{p}=$ 0.000) (Fig. 2).

\section{Fluorine intake}

When investigating the dietary fluorine intake, it was established that the consumption of $58.5 \%$ of the children did not reach up to the age-related physiological limit $(1 \mathrm{mg})^{16}$. In 28.3\% the intake complied with the recommendations and in $13.2 \%$ it exceeded the age-related reference value.

The mean daily fluorine intake values in the studied children's group were $0.8 \pm 0.37 \mathrm{mg}$. The resulting values were below the recommended limits $(1.0 \mathrm{mg})$. The difference was statistically significant $(\mathrm{p}=0.000)$ (Fig. 3).

\section{Magnesium intake}

The investigation of magnesium intake showed that none of the children exceeded the age-related reference values. The magnesium intake of $83 \%$ of all studied young patients was below the reference values and the remaining $17 \%$ were within the recommended limit.

The mean daily magnesium intake values were $139 \pm 43 \mathrm{mg}$, by $91 \mathrm{mg}$ less than the age-related recommended limit of $230 \mathrm{mg}^{16}$. The lowest recorded value was $68 \mathrm{mg}$ and the maximal one $261 \mathrm{mg}$. A statistically significant difference $(p=0.002)$ revealed between the recorded intake and the reference value was proven (Fig. 4).

\section{Iron intake}

A high rate (77.4\%) of the children examined by us showed iron intake under the age-related recommended limit. The dietary iron intake was within the limits for $13.2 \%$ of the group and $9.4 \%$ reported intake higher than the recommendations.

A mean daily intake of iron of $6.7 \pm 4.64 \mathrm{mg}$ was calculated, which did not reach up to the physiological recommended limit of $10 \mathrm{mg}^{16}$. The lowest reported value was $1.1 \mathrm{mg}$ and the maximal one $28.5 \mathrm{mg}$. The difference between the reported intake and the recommended limits was statistically significant $(\mathrm{p}=$ 0.002) (Fig. 5).

\section{Sodium intake}

Of all examined children $28.3 \%$ had sodium intake greater than the age-related recommendation. Adequate intake was determined in $26.4 \%$ of the group and $45.2 \%$ showed intake below the recommended limits. 


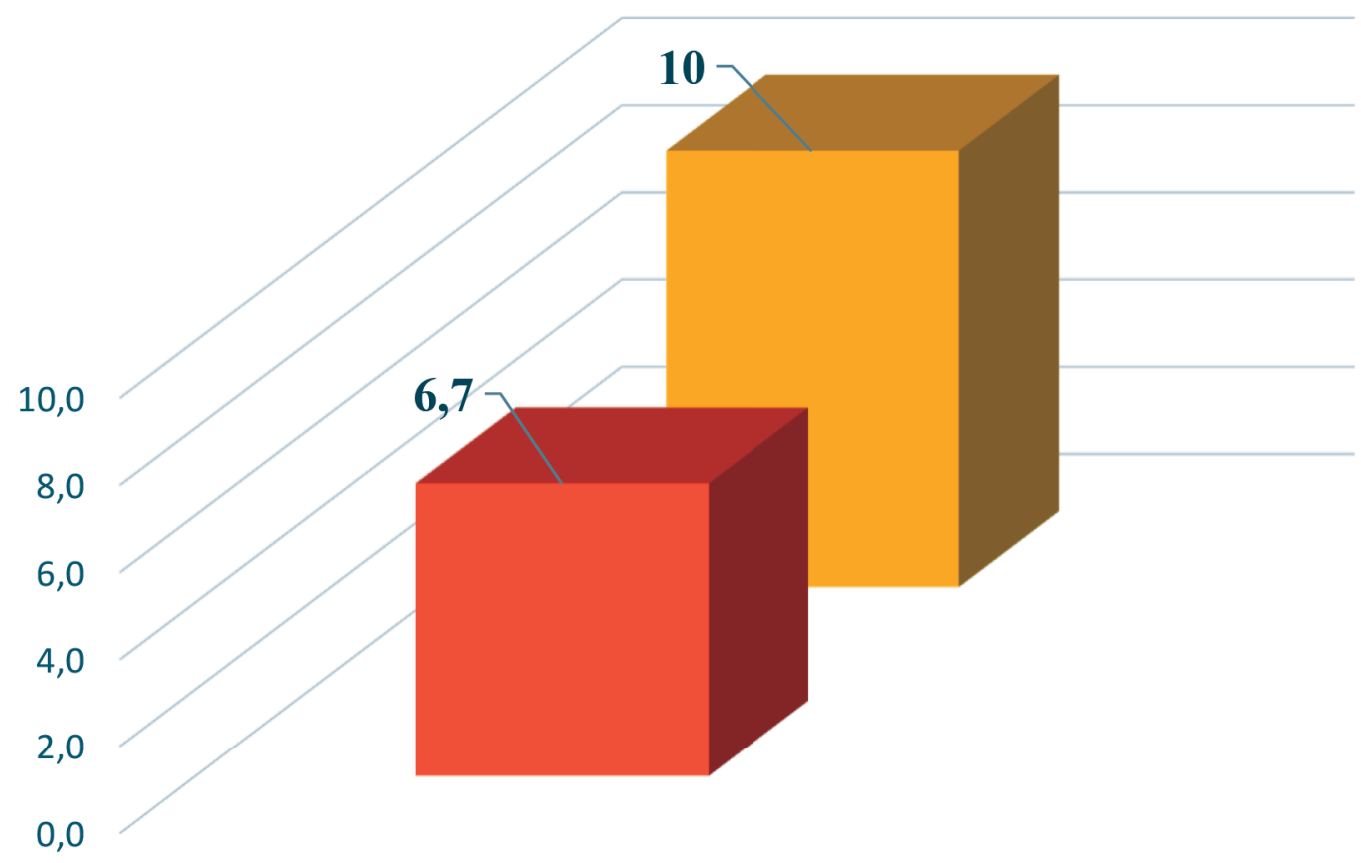

- Average daily intake $\quad$ Recommended intake

Fig. 5. Mean daily and recommended iron intake (mg)

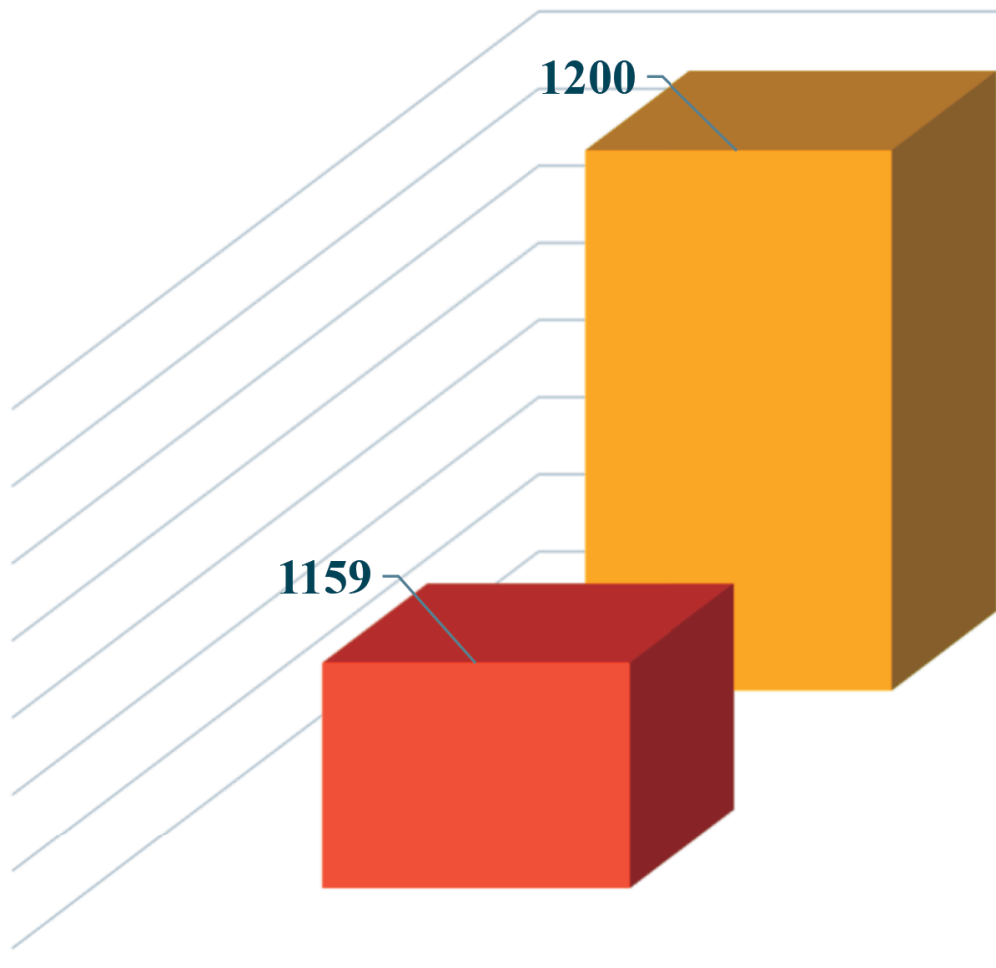

Average daily intake $\quad$ Recommended intake

Fig. 6. Mean daily and recommended sodium intake (mg) 


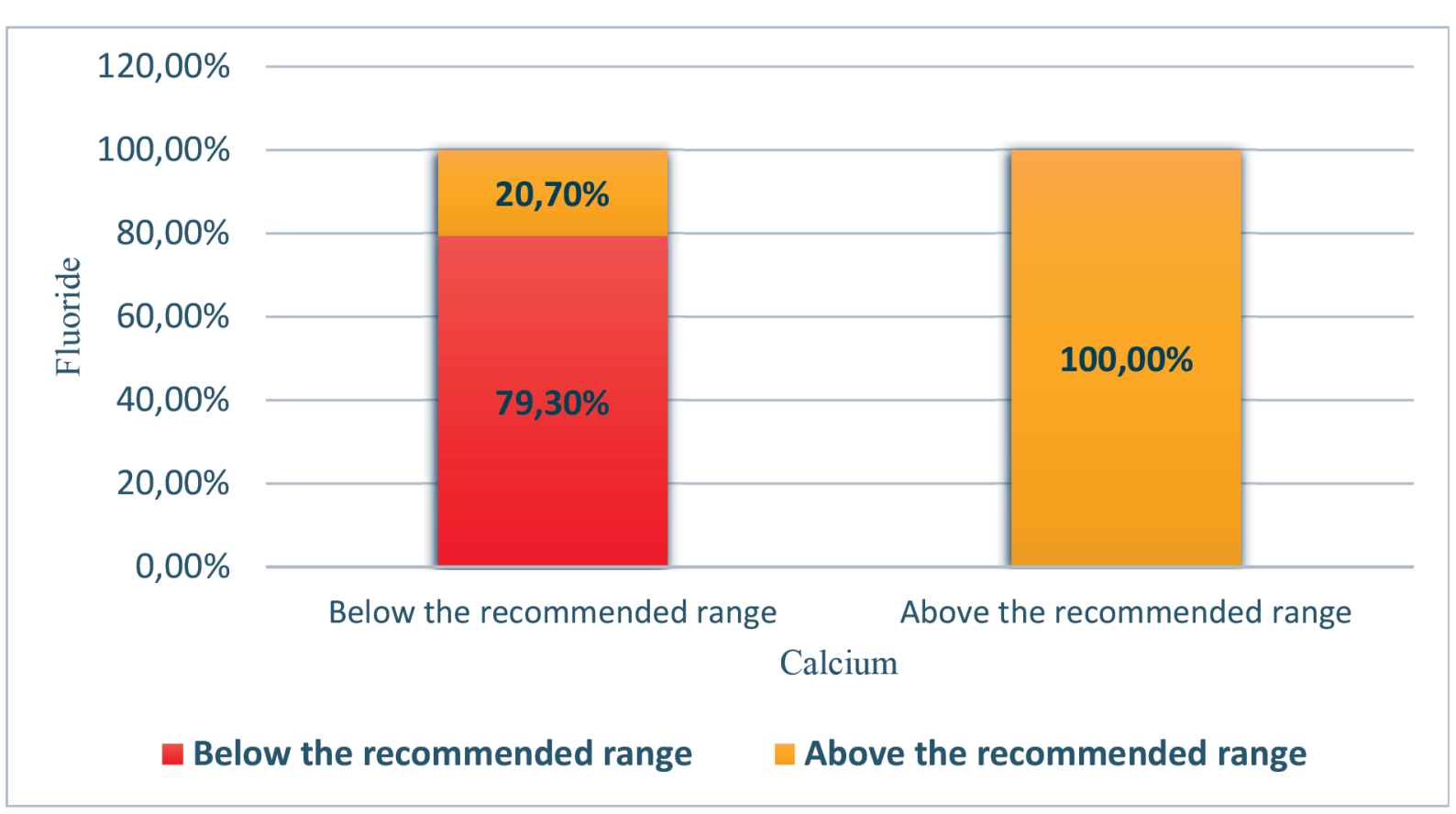

Fig. 7. Distribution of children according to the intake of calcium and fluoride

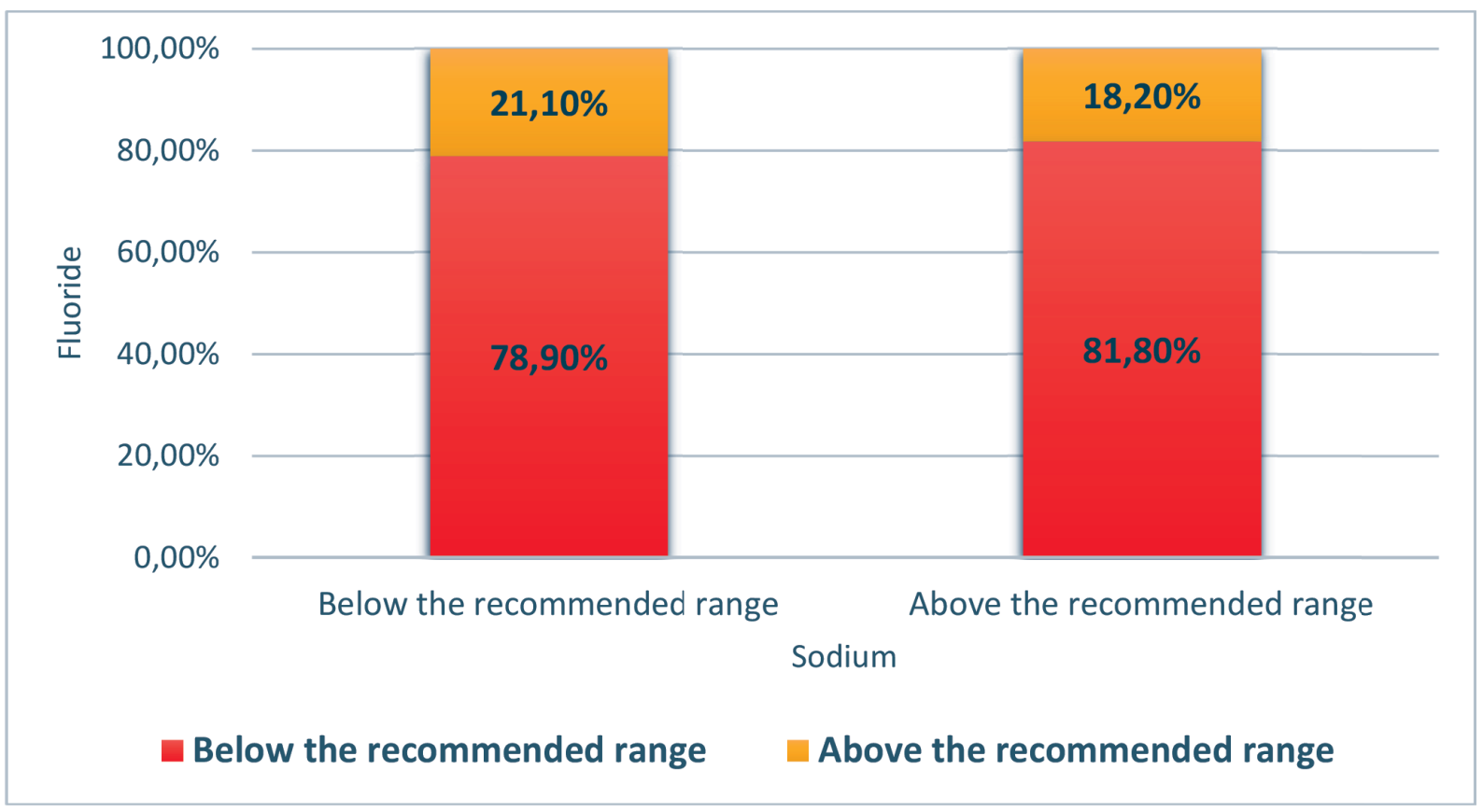

Fig. 8. Distribution of children according to the intake of sodium and fluoride

The analysis of the mean daily intake showed that the children consumed $1159 \pm 529 \mathrm{mg}$ as a mean daily, which complied with the age-related physiological needs (1200 mg) $)^{16}$ (Fig. 6).

The comparative analysis of the data revealed that there was no significant difference between the intake levels of calcium and fluorine in the examined group $\left(\chi^{2}=0.76, p>0.05\right)$ with more than $3 / 4(79.3 \%)$ of the children with low calcium intake had also low fluorine intake. On the other hand, all children with high calcium intake had also high fluorine intake (Fig. 7).

A similar trend was observed concerning sodium and fluorine import $\left(\chi^{2}=0.036, p>0.05\right)$, where more than $3 / 4$ of the children with low sodium intake level (78.9\%) showed also inadequate fluorine intake. It should be emphasized that $81.8 \%$ of the young patients 
with above-limit sodium intake had fluorine intake values below the limits (Fig. 8).

Considering the iron intake, $80.6 \%$ of the children with low iron values had the same level for fluorine and $66.7 \%$ of those with iron exceeding the recommended limits had reduced fluorine intake $\left(\chi^{2}=0.327, p>0,05\right)$.

\section{Discussion}

The analysis of the data concerning calcium intake showed that a great number of the examined children did not consume sufficient amounts of that inorganic element. The results derived by us confirmed the evidence communicated by other researchers ${ }^{17,18}$, proving that children with four and more caries had definitely lower mean daily calcium intake (496 and $511 \mathrm{mg}$, respectively).

Phosphorus has an essential role in the formation of the organic matrix of dental structures - it is a major structural unit of the apatite crystal. The mean daily intake of phosphorus of the children engaged in the survey was greater than the recommended limits. Some studies supported that this intake could reduce calcium levels in the organism as phosphorus and calcium effects were interrelated and interdependent because of their ability to form insoluble calcium phosphates $^{19,20}$. The values of dietary phosphorus, listed by other studies were even higher than those stated in the present survey ${ }^{17,21}$.

The data for magnesium intake in our investigated group was lower than the age-related recommended limits. According to Gupta ${ }^{20}$, the reduced intake of this inorganic element could disturb calcium-phosphorus metabolism thus causing decreased resistance of apatite crystals in dental structures. The obtained intake values of $139 \mathrm{mg}$ have been confirmed by other study ${ }^{18}$.

Fluorine ions are capable to displace calcium and hydroxyl groups in the apatite crystal of enamel and dentin, thus improving its resistance to carious processes? ${ }^{7}$. Its adequate dietary intake is particularly important for the proper development of dental structures. Besides that, we have to emphasize on its exogenous effect through preventive products providing caries-protective effect normalizing saliva $\mathrm{pH}^{22}$.

Fluorine intake of the studied group did not comply with age-related physiological limits. Certain studies in this field ${ }^{23,24}$ have also confirmed that children with multiple caries had mean daily fluorine intake not more than $0.74 \mathrm{mg}$ per day.

The determined low dietary intake of inorganic elements responsible for dental structures strength can be explained with lack of variety of food products in the diet in spite of the current possibilities of the food market.
This study also covered investigation of iron and sodium intake as those inorganic elements are associated directly with the general health status and indirectly with the carious processes.

Our data for iron intake corresponded to the results determined up to now by other studies ${ }^{20}$, indicating enhanced risk for deficiency of this mineral in young children.

According to some sources it is difficult to find a relationship between iron deficiency and later caries predisposition; nevertheless, an experiment with rats has proven ${ }^{26}$ that even mild deviations from the adequate intake could cause outlined susceptibility to development of caries. Besides that, certain studies ${ }^{26,27}$ on iron serum levels and incidence/prevalence of caries in childhood (Decayed, Missing, Filled Teeth (DMFT) index) have confirmed that children with iron deficiency have much higher DMFT index than those with adequate iron intake.

The recommended sodium intake limit for children aged $3-7$ years is $1.2 \mathrm{~g}$. According to the World Health Organization ${ }^{28}$, the mean daily consumption of sodium should not exceed $5 \mathrm{~g} /$ day. The children from our studied group reported sodium intake complying with the age-related recommended limit.

The identification of the role of each trace element for dental health is difficult because it is not possible to isolate the effect of each effect in the diet. The particular inorganic substances are contained in various amounts and ratios in the different foods. Some studies ${ }^{29,30}$ on the identification of the role of the individual minerals in the resistance of dental enamel have revealed that sometimes even small amounts of a particular trace element, in combination with others of the kind, could have beneficial effect. The effect of each of the presented elements could be modulated through dietary effect.

Based only on the content of minerals in the dietary intake it is difficult to assess the level of sufficiency complying with physiological needs as their bio accessibility and bio availability have also particular importance.

\section{Conclusion}

The examined children have reduced dietary intake of inorganic substances, such as calcium, magnesium, iron and fluorine, normal sodium intake and elevated intake of phosphorus.

The obtained data can be included in the relevant data bases for exchange of information on ECC. The data are useful in building up adequate diets pursuing the treatment of the risk group of children with caries.

Complying with WHO recommendations for more comprehensive studying of oral diseases, we 
initiated the presented study on the role of dietary components in the development of ECC and the need to modulate children's diet, aiming at achieving higher level of prevention efficacy.

\section{Compliance with Ethics Requirements:}

„The authors declare no conflict of interest regarding this article"

„The authors declare that all the procedures and experiments of this study respect the ethical standards in the Helsinki Declaration of 1975, as revised in 2008(5), as well as the national law. Informed consent was obtained from all the patients included in the study"

"No funding for this study“

\section{References}

1. Da Silveira Moreira R. Epidemiology of dental caries in the world, oral health care. Pediatric, Research, Epidemiology and Clinical Practices, Prof. Mandeep Virdi (Ed.), ISBN: 978-953-51-0133-8, InTech, 2012, Available from: http://www. intechopen.com/books/oral-health-care-pediatric-research-epidemiology-andclinical-practices/epidemiology-of-dental-caries-in-the-world.

2. Dimitrov E, Georgieva M, Andreeva R, Dimova-Gabrovska $\mathrm{M}$, Arnautska H. Caries prevalence among 5-7-year-old children in north-east Bulgaria. Journal of IMAB 2017, 23(3):1633-1636.

3. Tinanoff N, Baez R, Guillory C, et al. Early childhood caries epidemiology, etiology, risk assessment, societal burden, management, education, and policy: global perspective. International Journal of Pediatric Dentistry 2019; 29(3): 238-248.

4. O'Keefe E. Early Childhood Caries. Journal of Evidence-Based Dental Practice 2013; 14(2):40-41.

5. Andreeva R. The assessment of food habits in children and the risk of premature tooth extraction. International Journal of Science and Research 2016;5(5):2110-2111.

6. Attari N, Robert JF. Restoration of primary teeth with crowns-a systematic review of the literature. European Archives of Paediatric Dentistry 2006;7(2):58-62.

7. Peneva M, Tsolova E, Kabakchieva R, Rashkova M. Prophylaxis of oral diseases. $2^{\text {nd }}$ ed, East West. Sofia, 2009: 100-187. [in Bulgarian]

8. Psoter W, Gebrian B, Prophete S, Reid B, Katz R. Effect of early childhood malnutrition on tooth eruption in Haitian adolescents. Community Dentistry and Oral Epidemiology 2008;36(2):179-189.

9. Tinanoff N, Palmer C. Dietary determinants of dental caries and dietary recommendations for preschool children. Journal of Public Health Dentistry 2000; 60(3):197-206.

10. Bakardzhiev P, Toneva N, Georgieva M, Peneva M, Targova S. Knowledge of nutrition and oral hygiene of children in school age. Problems of Dental medicine 2013;39(1):19-23. [in Bulgarian]

11. Mojon P, Budtz-Jorgensen E, Rapin CH. Relationship between oral health and nutrition in very old people. Age and Ageing 1999; 28(5):463-468.

12. Sheiham A. Dental caries affects body weight, growth and quality of life in pre-school children. British Dental Journal 2006; 201(10): 625-626
13. Clarke M, Locker D, Berall G, Pencharz P, Kenny D, Judd P. Malnourishment in a population of young children with severe Early childhood caries. Journal of Pediatric Dentistry 2006; 28(3): 254-259

14. Abolfotouh MA, Hassan KH, Khattab MS, Youssef RM, Sadek A, El-Sebaiei M. Dental caries: experience in relation to wasting and stunted growth among schoolboys in Abha, Saudi Arabia. Annals of Saudi Medicine 2000; 20(5-6):360-363.

15. Kurtisheva M, Ribarova F, Angelova K. Modelling preventive diet by „Alimenta“ software. Acta Medica Bulgarica 2004; XXXI(1): 26-31.

16. Ordinance No. 1 of January 22, 2018 on the physiological norms for nutrition of the population. Ministry of health Bulgaria. Available from: http://www.mh.government.bg/ media/filer_public/2018/02/13/naredba1-22-01-2018-fiziologicni-normi-hranene-naselenie.pdf

17. Lin H, Lin J, Hu S, Kuo H, Yang Y. Association of dietary calcium, phosphorus, and magnesium intake with caries status among schoolchildren. The Kaohsiung Journal of Medical Sciences 2014; 30(4):206-212.

18. Yen C, Huang Y, Hu S. Relationship between dietary intake and dental caries in preschool children. International Journal for Vitamin and Nutrition Research 2010; 80(3):205-15.

19. Calvo M.S. The effects of high phosphorus intake on calcium homeostasis. In: Draper H.H. (eds) Nutrition and Osteoporosis. Advances in Nutritional Research, vol 9. Springer, Boston, MA 1994: 183-207.

20. Gupta A, Khandelwal R, Kapil U. Interrelationship between dental health status and nutritional status among elderly subjects in India. Journal of Family Medicine and Primary Care 2019;8(2):477-481

21. Marshall T, Levy S, Broffitt B, et al. Dental caries and beverage consumption in young children. Pediatrics 2003; 112(3): 184-191.

22. Paneva S, Pashov I, Angelova I, Nikolov A. Fluor - dental health - for and against. To the teacher with admiration and bow, Collective monography. Medical College „Yordanka Filaretova“. Sofia. 2019; 175- 185.

23. Guha-Chowdhury N, Drummond B, Smillie C. Total fluoride intake in children aged 3 to 4 years - a longitudinal study. Journal of Dental Research 1996;75(7):1451-1457.

24. Ekstrand J. Fluoride intake in early infancy. The Journal of Nutrition 1989;119(12): 1856-1860.

25. Miguel J, Bowen W, Pearson S. Influence of iron alone or with fluoride on caries development in desalivated and intact rats. Caries Research 1997; 31(3):244-248.

26. Sadeghi M, Darakhshan R, Bagherian A. Is there an association between early childhood caries and serum iron and serum ferritin levels? Dental Research Journal 2012; 9(3): 294298.

27. Pourhashemi SJ, Golestan B, Keshavarz S. Micronutrients Fe, $\mathrm{Zn}$ and $\mathrm{Ca}$ and their relationship with anthropometric indices and dental health among children. Tehran University Medical Journal 2008; 65(12):72-7.

28. World Health Organization. Sodium intake for adults and children. Guideline. ISBN: 978 92-4-150483-6.

29. Alvarez JO1, Caceda J, Woolley TW, et al. A longitudinal study of dental caries in the primary teeth of children who suffered from infant malnutrition. Journal of Dental Research 1993; 72(12):1573-1576.

30. Pashov I, Nikolov A. Food - risk and preventive factor for tooth caries. To the teacher with admiration and bow. Collective monography. Medical College „Yordanka Filaretova“ Sofia. 2019; 163-175. 